\title{
Essential and Heavy Metals Content in Wild and Cultivated Mentha Species from Bosnia and Herzegovina
}

University of Sarajevo, Faculty of Pharmacy, Zmaja od Bosne 8,

71000 Sarajevo, Bosnia and Herzegovina

\begin{abstract}
Both essential and heavy metals play important roles in human health and diseases. The aim of the present study was to determinate concentrations of essential and heavy metals, such as $\mathrm{Na}, \mathrm{K}, \mathrm{Ca}, \mathrm{Mg}, \mathrm{Cu}, \mathrm{Cr}, \mathrm{Mn}, \mathrm{Ni}, \mathrm{Fe}, \mathrm{Pb}$, Zn, and Cd, in the leaves of Mentha longifolia L. and Mentha $\times$ piperita L. The plant material samples were collected from six different locations in Bosnia and Herzegovina $(B \& H)$, at selected distances from heavy metal pollution sources. Wet digestion was applied for the dissolution of samples and essential and heavy metals concentrations were analysed by flame atomic absorption spectrometry and (FAAS). Results of the analysis (expressed as $\mathrm{mg} \mathrm{g}^{-1}$ ) were obtained as follows: Na 2.08-4.12; K 14.85-22.54; Ca 9.06-15.53; Mg 1.93-3.12; Cu 0.01-0.05; Cr 0.70-0.90; Mn 0.02-0.09; Ni 1.10-7.00; Fe 0.06-1.11; Pb 0.10-0.90; Zn 0.01-0.04. The cadmium concentration in all samples was below the detection limit by FAAS. Strong correlation between $\mathrm{Ni}$ and $\mathrm{Pb}$, as well as $\mathrm{Ni}$ and Fe, confirmed mostly environmental and processing influence/impact. In conclusion, Mentha longifolia L. and Mentha $\times$ piperita L. can be used in daily consumption considering the high content of essential metals Fe, $\mathrm{Cu}, \mathrm{Mg}$, and $\mathrm{Zn}$, and their beneficial effects on normal body function. In addition, there is no risk of heavy metals to human health after consuming these samples due to lower concentrations.
\end{abstract}

\section{Keywords}

Essential metals, heavy metals, Mentha species, AAS

\section{Introduction}

Medicinal plants are commonly used in traditional medicine as the raw material for many herbal formulations. They contain various substances which can originate from the soil, water, or air and have benefits for humans. Some of these substances are elements/metals present in a wide range of concentration/content. Essential elements (microand macro-elements) are important for normal growth and functioning of living organisms. Also, medicinal plants may contain high levels of heavy metals, which cause toxicity and severe metabolic disturbances. Essential metals as micro- and macro-elements $(\mathrm{Cu}, \mathrm{Zn}, \mathrm{Cr}, \mathrm{Fe}, \mathrm{Mn}, \mathrm{K}, \mathrm{Na}$, $\mathrm{Mg}$, and $\mathrm{Ca}$ ) are needed at low concentrations for normal functioning of enzyme systems, formation of haemoglobin, synthesis of vitamins, and for growth, development and photosynthesis in plants. ${ }^{1,2}$ On the other hand, toxic elements, such as $\mathrm{Pb}, \mathrm{Cd}$, and $\mathrm{Ni}$, are not necessary to the human body and may cause severe consequences to human health..$^{3-7}$ In B\&H, Mentha species have been used as tea in traditional medicine since ancient times, as well as in different herb formulations as ingredients for making creams, perfumes, soaps, etc. In this work, the content of micro- and macro-elements as well as of some heavy metals was determined in two Mentha species - wild and cultivated - using flame atomic absorption spectrometry. In addition, correlation analysis of the total elements content in wild and cultivated Mentha samples was performed, with respect to their element composition as the impact of environmental and other factors.

\section{Experimental}

\subsection{Materials and methods}

The plant samples of Mentha longifolia L. and Mentha $\times$ piperita L. were collected from June to October 2018, at six different locations in B\&H: 3 wild and 3 cultivated at selected distances from heavy metal pollution sources-urban locations (100 km and range of elevation 300-1200 m
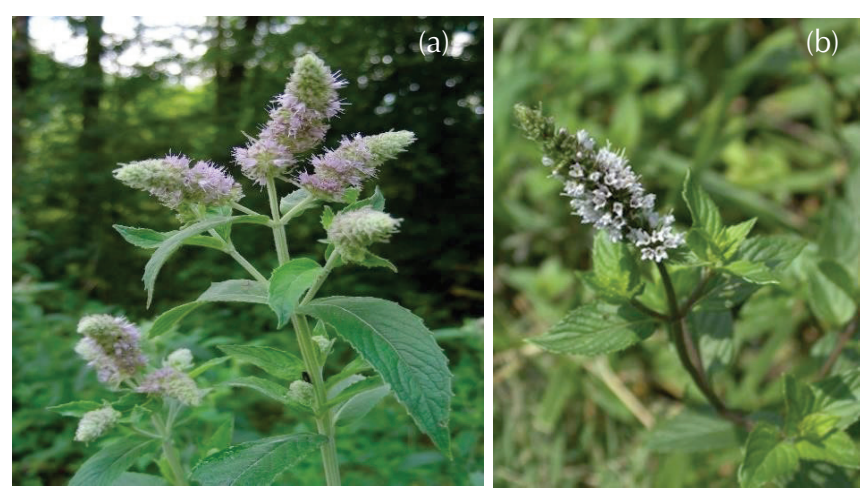

Fig. 1 - Mentha longifolia L. (a) and Mentha $\times$ piperita L. (b) Slika 1 - Mentha longifolia L. (a) i Mentha $\times$ piperita L. (b) 
for wild samples in Bugojno, Rudo, and Sarajevo; and from 3 to $30 \mathrm{~km}$ with average elevation of $900 \mathrm{~m}$ for cultivated samples in Ključ, Travnik, and Brčko). Fresh leaves of the wild species were collected randomly in sufficient quantities (1 $\mathrm{kg}$ to provide representative samples). Samples were cut into small pieces and air-dried in the shade for two weeks, then powdered, sieved, and stored in paper bags for element analysis. Samples of cultivated species were available as tea-bags, packed in boxes by local and domestic manufacturers.

\subsection{Analytical quality control}

All chemicals and reagents were of analytical grade: $\mathrm{HNO}_{3}$ (65 \%; Sigma Aldrich, Steinheim, Germany), $\mathrm{H}_{2} \mathrm{O}_{2}$ (30 \%; Semikem, Sarajevo, Bosnia and Herzegovina), and $\mathrm{HCl}$ (37 \%; Sigma Aldrich, Steinheim, Germany). Milli-Q water was used throughout the experimental work. Standard solutions of all analysed elements were provided by Merck (Darmstadt, Germany). Concentration of stock standard solution of all elements was $1000 \mathrm{mgl}^{-1}$ while calibration standard solutions of each element were obtained by appropriate dilution of the stock solutions.

All of the volumetric glassware was of A grade, and soaked in nitric acid $(\varphi=10 \%)$ for $12 \mathrm{~h}$ and rinsed with Milli-Q water before use. The sample and blank analyses were performed in triplicate, and the standard deviation was calculated. The value of the detection limit (LOD) for metals $\mathrm{Na}$, $\mathrm{K}, \mathrm{Mg}, \mathrm{Ca}, \mathrm{Cu}, \mathrm{Cr}, \mathrm{Mn}, \mathrm{Ni}, \mathrm{Fe}, \mathrm{Pb}, \mathrm{Zn}$, and $\mathrm{Cd}$ were 0.25 ; $3.00 ; 0.20 ; 1.50 ; 0.25 ; 0.006 ; 0.20 ; 0.01 ; 6.00 ; 1.00 ; 0.50$; and $0.002 \mathrm{mgl}^{-1}$, respectively. The limits of detection were calculated from the values of the content of individual elements in the blank and the standard deviation of repeated measurements of the blank. Spiked samples were used to test the methods at varying concentrations of analyte, and the percent recovery was calculated. The acceptable recovery of known additions ranged between 89-104 \%.

\subsection{Sample preparation and elements analysis by FAAS}

Elements in the plant samples were extracted following the acid wet digestion procedure: about $2 \mathrm{~g}( \pm 0.1 \mathrm{mg})$ of leaves was weighed in the PTFE digestion vessels, $10 \mathrm{ml}$ of the mixture containing $65 \% \mathrm{HNO}_{3}$, and $37 \%$ $\mathrm{HCl}(\varphi=2: 1)$ was added and heated on a hotplate at a moderate temperature $\left(40-50{ }^{\circ} \mathrm{C}\right)$ until the brown gases had evaporated. After cooling at room temperature, 1 I of $\mathrm{H}_{2} \mathrm{O}_{2}(\varphi=30 \%)$ was added and heating continued at the same temperature range until the solution became clear. The cooled solutions were filtered through a quantitative filter paper (Whatman No. 42) into $50 \mathrm{ml}$ calibrated flasks and diluted to full volume with Milli-Q water. Prepared solutions were stored at $4{ }^{\circ} \mathrm{C}$ until analysis.

Concentrations of essential metals $(\mathrm{Na}, \mathrm{K}, \mathrm{Mg}, \mathrm{Ca}, \mathrm{Cu}, \mathrm{Cr}$, $\mathrm{Mn}, \mathrm{Fe}$, and $\mathrm{Zn}$ ) and heavy metals $(\mathrm{Ni}, \mathrm{Pb}$, and $\mathrm{Cd}$ ) in samples of Mentha species (wild and cultivated) were determined by FAAS using the instrumental conditions set by the manufacturer (AA240FS, Varian, Australia).

\section{Results and discussion}

In this work, content of essential and heavy metals was determined in two Mentha species, Mentha longifolia L. and Mentha $\times$ piperita L. from B\&H, collected at six different locations. Results of the analysis are presented in Table 1 (for wild herb species samples) and Table 2 (for cultivated herb species samples), as the mean of three parallel determinations with indicated standard deviation (SD).

Table 1 shows the elements content in Mentha longifolia L. (wild herb species). The content ranged from $0.10 \mathrm{mg} \mathrm{g}^{-1}$ for $\mathrm{Pb}$ to $755.00 \mathrm{mg} \mathrm{g}^{-1}$ for $\mathrm{Fe}$, while in Table 2, metals content in Mentha $\times$ piperita L. (cultivated herb species) ranged from $0.40 \mathrm{mg} \mathrm{g}^{-1}$ for $\mathrm{Pb}$ to $1108.40 \mathrm{mgg}^{-1}$ for Fe. The concentrations of $\mathrm{Cr}$ and $\mathrm{Cd}$ were below $\mathrm{WHO}^{15,17}$ permissible limits in wild herb samples. Also, in the Mentha herb, the highest concentration was detected for Fe and the lowest for $\mathrm{Pb}$. Relatively low content of $\mathrm{Cu}$ in wild samples compared to the content of $\mathrm{Zn}$ is due to the fact that higher $\mathrm{Cu}$ concentrations mean lower $\mathrm{Zn}$ content, because higher concentrations of $\mathrm{Cu}$ in the soil relative to $\mathrm{Zn}$ can reduce the availability of $\mathrm{Zn}$ to a plant, due to competition for the same sites for absorption into the plant root. ${ }^{23-25}$

In cultivated herb samples (Table 2), no $\mathrm{Cd}$ was detected in all three samples, while the highest concentration was detected for Fe and the lowest concentrations for $\mathrm{Pb}^{24} \mathrm{The}$ detected high concentrations of Fe and $\mathrm{Zn}$ in the samples of cultivated species of Mentha confirmed the results of previous published papers that the deficiency of $\mathrm{Zn}$ leads to a deficiency of Fe in plants. ${ }^{24,25}$

Twelve elements ( $\mathrm{Na}, \mathrm{K}, \mathrm{Ca}, \mathrm{Mg}, \mathrm{Cr}, \mathrm{Cu}, \mathrm{Mn}, \mathrm{Fe}, \mathrm{Ni}, \mathrm{Cd}$, $\mathrm{Pb}$, and $\mathrm{Zn}$ ) were compared in all Mentha samples by correlation analysis using Microsoft Excel. The element correlations (Pearson, $r$ ) in the studied wild and cultivated Mentha samples from various sampling sites are reported in Tables 3 and 4. Pearson correlation coefficient, $r$, has a value between 0 and 1 , and full correlation is represented as 1 , while the absence of correlation is represented as $r<0$.

Due to the fact that the content for $\mathrm{Cr}$ and $\mathrm{Cd}$ was not analysed in the test species Mentha longifolia L., because the values were below the limit of detection with FAAS, no Pearson's correlation was performed. Similarly, in Mentha piperita L. samples, no correlation was performed for $\mathrm{Cd}$, because the concentration for this heavy metal was below the detection limit of the used method for analysis. ${ }^{8}$ Full, strong, and moderate or weak correlations, and absence of correlation with $r$ values of $0.9 \leq r<1,0.5 \leq r<0.8$, $0.2 \leq r<0.5$, and $r \leq 0$, respectively, were found between major macro-elements and trace micro-elements in both Mentha species. These correlations are of the result of the relationship that macro- and micro-elements have in living systems, both in humans and plants, and they are the result of biological, chemical, and metabolic reactions and various signalling pathways. Also, a good correlation between two elements points to the same source of these elements in plant as well in soil (e.g., for $\mathrm{Cu}$ and $\mathrm{Fe}, \mathrm{Cu}$, and $\mathrm{Zn}$, as well as $\mathrm{Cu}$ and $\mathrm{Ni}$ ). 
Table 1 - Content of essential and heavy metals (mean \pm SD) $\mathrm{mg} \mathrm{g}^{-1}$ in wild Mentha species (Mentha longifolia L.) ( $n=3$ )

Tablica 1 - Esencijalni i teški metali (srednja vrijednost \pm SD) $\mathrm{mgg}^{-1}$ u samonikloj vrsti metvice (Mentha longifolia L.) ( $n=3$ )

\begin{tabular}{|c|c|c|c|c|}
\hline $\begin{array}{l}\text { Elements } \\
\text { Elementi }\end{array}$ & $\begin{array}{l}\text { Sample I } \\
\text { Uzorak I }\end{array}$ & $\begin{array}{l}\text { Sample II } \\
\text { Uzorak II }\end{array}$ & $\begin{array}{l}\text { Sample III } \\
\text { Uzorak III }\end{array}$ & $\begin{array}{l}\text { Literature values } / \mathrm{mg} \mathrm{g}^{-1} \\
\text { Vrijednosti u literaturi } / \mathrm{mg} \mathrm{g}^{-1}\end{array}$ \\
\hline $\mathrm{Na} / \mathrm{mgg}^{-1}$ & $2.08 \pm 0.36$ & $2.08 \pm 0.03$ & $2.20 \pm 0.09$ & $\begin{array}{l}4.90^{12} \\
1.17^{14} \\
0.48^{5}\end{array}$ \\
\hline $\mathrm{K} / \mathrm{mgg}^{-1}$ & $15.00 \pm 0.21$ & $14.85 \pm 0.40$ & $15.08 \pm 0.80$ & $\begin{array}{l}23.40^{5} \\
7.23^{14} \\
0.60^{12}\end{array}$ \\
\hline $\mathrm{Mg} / \mathrm{mgg}^{-1}$ & $2.07 \pm 0.02$ & $1.93 \pm 0.03$ & $2.07 \pm 0.06$ & $\begin{array}{l}7.80^{12} \\
4.83^{5} \\
3.83^{14}\end{array}$ \\
\hline $\mathrm{Ca} / \mathrm{mgg}^{-1}$ & $15.32 \pm 0.24$ & $9.57 \pm 0.94$ & $10.03 \pm 0.10$ & $\begin{array}{c}12.40^{5} \\
10.32^{14} \\
3.80^{12}\end{array}$ \\
\hline $\mathrm{Cu} / \mathrm{mgg}^{-1}$ & $7.00 \pm 0.01$ & $7.30 \pm 0.01$ & $10.00 \pm 0.01$ & $\begin{array}{c}10-32^{23} \\
3.82-12.32^{7} \\
10.60^{24} \\
1.68^{18}\end{array}$ \\
\hline $\mathrm{Cr} / \mathrm{mgg}^{-1}$ & $\leq \mathrm{LOD}^{*}$ & $\leq \mathrm{LOD}^{*}$ & $\leq \mathrm{LOD}^{*}$ & $\begin{array}{c}28-43^{6} \\
2.40^{23} \\
1.34^{5} \\
0.005^{18}\end{array}$ \\
\hline $\mathrm{Mn} / \mathrm{mgg}^{-1}$ & $40.30 \pm 0.01$ & $21.30 \pm 0.01$ & $37.80 \pm 0.01$ & $\begin{array}{c}11-276^{6} \\
114^{24} \\
53.5^{5} \\
32.70^{23}\end{array}$ \\
\hline $\mathrm{Ni} / \mathrm{mgg}^{-1}$ & $7.00 \pm 0.01$ & $3.70 \pm 0.01$ & $6.60 \pm 0.01$ & $\begin{array}{l}7.20^{12} \\
3.20^{2} \\
2.38^{17} \\
1.02^{24}\end{array}$ \\
\hline $\mathrm{Fe} / \mathrm{mg} \mathrm{g}^{-1}$ & $645 \pm 0.01$ & $755 \pm 0.01$ & $659 \pm 0.01$ & $\begin{array}{c}150.57-821.02^{8} \\
532,281^{11} \\
275.6-354.6^{10} \\
293^{20} \\
263^{24} \\
108^{5}\end{array}$ \\
\hline $\mathrm{Pb} / \mathrm{mgg}^{-1}$ & $0.10 \pm 0.01$ & $0.60 \pm 0.01$ & $0.90 \pm 0.01$ & $\begin{array}{c}1.44-9.24^{7} \\
0.74^{23} \\
0.71^{24} \\
0.82^{17}\end{array}$ \\
\hline $\mathrm{Zn} / \mathrm{mgg}^{-1}$ & $13.90 \pm 0.01$ & $14.50 \pm 0.01$ & $29.90 \pm 0.01$ & $\begin{array}{c}32-126^{6} \\
12.65-52.97^{7} \\
34.00^{24} \\
21.00^{5}\end{array}$ \\
\hline $\mathrm{Cd} / \mathrm{mgg}^{-1}$ & $\leq \mathrm{LOD}^{*}$ & $\leq \mathrm{LOD}^{*}$ & $\leq \mathrm{LOD}^{*}$ & $\begin{array}{l}0.58^{17} \\
0.15^{24} \\
0.11^{23} \\
0.063^{8}\end{array}$ \\
\hline
\end{tabular}


Table 2 - Content of essential and heavy metals $\left(\mathrm{mgg}^{-1} \pm \mathrm{SD}\right)$ in cultivated Mentha species (Mentha $\times$ piperita L.) $(n=3)$ Tablica 2 - Esencijalni i teški metali (srednja vrijednost \pm SD) $\mathrm{mgg}^{-1}$ u kultiviranoj vrsti metvice (Mentha $\times$ piperita L.) $(n=3)$

\begin{tabular}{|c|c|c|c|c|}
\hline $\begin{array}{l}\text { Elements } \\
\text { Elementi }\end{array}$ & $\begin{array}{l}\text { Sample I } \\
\text { Uzorak I }\end{array}$ & $\begin{array}{l}\text { Sample II } \\
\text { Uzorak II }\end{array}$ & $\begin{array}{l}\text { Sample III } \\
\text { Uzorak III }\end{array}$ & $\begin{array}{l}\text { Literature values } / \mathrm{mg} \mathrm{g}^{-1} \\
\text { Vrijednosti u literaturi } / \mathrm{mg} \mathrm{g}^{-1}\end{array}$ \\
\hline $\mathrm{Na} / \mathrm{mgg}^{-1}$ & $4.11 \pm 2.01$ & $3.82 \pm 0.03$ & $3.70 \pm 0.25$ & $\begin{array}{l}4.90^{12} \\
1.17^{14} \\
0.48^{5}\end{array}$ \\
\hline $\mathrm{K} / \mathrm{mgg}^{-1}$ & $16.99 \pm 0.68$ & $22.54 \pm 0.02$ & $20.97 \pm 2.12$ & $\begin{array}{l}23.40^{5} \\
7.23^{14} \\
0.60^{12}\end{array}$ \\
\hline${\mathrm{Mg} / \mathrm{mgg}^{-1}}^{-1}$ & $3.12 \pm 0.27$ & $2.96 \pm 0.01$ & $2.17 \pm 0.08$ & $\begin{array}{l}7.80^{12} \\
4.83^{5} \\
3.83^{14}\end{array}$ \\
\hline $\mathrm{Ca} / \mathrm{mgg}^{-1}$ & $15.53 \pm 0.35$ & $15.33 \pm 0.34$ & $9.08 \pm 0.27$ & $\begin{array}{c}12.40^{5} \\
10.32^{14} \\
3.80^{12}\end{array}$ \\
\hline $\mathrm{Cu} / \mathrm{mgg}^{-1}$ & $4.46 \pm 0.06$ & $12.00 \pm 0.01$ & $12.50 \pm 0.01$ & $\begin{array}{c}10-32^{23} \\
3.82-12.32^{7} \\
10.60^{24} \\
1.68^{18}\end{array}$ \\
\hline $\mathrm{Cr} / \mathrm{mgg}^{-1}$ & $0.70 \pm 0.01$ & $0.90 \pm 0.01$ & $0.80 \pm 0.01$ & $\begin{array}{c}28-43^{6} \\
2.40^{23} \\
1.34^{5} \\
0.005^{18}\end{array}$ \\
\hline $\mathrm{Mn} / \mathrm{mgg}^{-1}$ & $94.00 \pm 0.01$ & $85.20 \pm 0.01$ & $69.20 \pm 0.01$ & $\begin{array}{c}11-276^{6} \\
114^{24} \\
53.5^{5} \\
32.70^{23}\end{array}$ \\
\hline $\mathrm{Ni} / \mathrm{mgg}^{-1}$ & $4.60 \pm 0.01$ & $1.10 \pm 0.01$ & $3.70 \pm 0.01$ & $\begin{array}{l}7.20^{12} \\
3.20^{23} \\
2.38^{17} \\
1.02^{24}\end{array}$ \\
\hline $\mathrm{Fe} / \mathrm{mgg}^{-1}$ & $1108 \pm 0.16$ & $619 \pm 0.03$ & $644 \pm 0.05$ & $\begin{array}{c}150.57-821.02^{8} \\
532,281^{11} \\
275.6-354.6^{10} \\
293^{20} \\
263^{24} \\
108^{5}\end{array}$ \\
\hline $\mathrm{Pb} / \mathrm{mgg}^{-1}$ & $0.60 \pm 0.01$ & $0.40 \pm 0.01$ & $0.90 \pm 0.01$ & $\begin{array}{c}1.44-9.24^{7} \\
0.74^{23} \\
0.71^{24} \\
0.82^{17}\end{array}$ \\
\hline $\mathrm{Zn} / \mathrm{mgg}^{-1}$ & $31.70 \pm 0.01$ & $38.60 \pm 0.02$ & $39.30 \pm 0.01$ & $\begin{array}{c}32-126^{6} \\
12.65-52.97^{7} \\
34.00^{24} \\
21.00^{5}\end{array}$ \\
\hline $\mathrm{Cd} / \mathrm{mgg}^{-1}$ & $\leq \mathrm{LOD}^{*}$ & $\leq \mathrm{LOD}^{*}$ & $\leq \mathrm{LOD}^{*}$ & $\begin{array}{l}0.58^{17} \\
0.15^{24} \\
0.11^{23} \\
0.063^{8}\end{array}$ \\
\hline
\end{tabular}


Table 3 - Element correlations (Pearson, $r$ ) in wild species of Mentha longifolia L.

Tablica 3 - Korelacija elemenata (Pearson, $r$ ) u divljim vrstama Mentha longifolia L.

\begin{tabular}{c|c|c|c|c|c|c|c|c|c|c}
\hline $\begin{array}{c}\text { Elements } \\
\text { Elementi }\end{array}$ & $\mathrm{Na}$ & $\mathrm{K}$ & $\mathrm{Ca}$ & $\mathrm{Mg}$ & $\mathrm{Cu}$ & $\mathrm{Mn}$ & $\mathrm{Ni}$ & $\mathrm{Fe}$ & $\mathrm{Pb}$ & $\mathrm{Zn}$ \\
\hline $\mathrm{Na}$ & 1 & 0.75 & -0.43 & 0.53 & 0.99 & 0.40 & 0.86 & -0.40 & 0.78 & 0.99 \\
\hline $\mathrm{K}$ & & 1 & 0.27 & 0.96 & 0.68 & 0.90 & 0.31 & -0.91 & 0.18 & 0.73 \\
\hline $\mathrm{Ca}$ & & & 1 & 0.54 & -0.52 & 0.66 & -0.83 & -0.65 & -0.90 & -0.47 \\
\hline $\mathrm{Mg}$ & & & & 1 & 0.44 & 0.99 & 0.02 & -0.99 & -0.12 & 0.50 \\
\hline $\mathrm{Cu}$ & & & & & 1 & 0.31 & 0.90 & -0.31 & 0.84 & 0.99 \\
\hline $\mathrm{Mn}$ & & & & & & 1 & -0.13 & -0.99 & -0.26 & 0.36 \\
\hline $\mathrm{Ni}$ & & & & & & & 1 & 0.13 & 0.99 & 0.88 \\
\hline $\mathrm{Fe}$ & & & & & & & & 1 & 0.26 & -0.36 \\
\hline $\mathrm{Pb}$ & & & & & & & & & 1 & 0.81 \\
\hline $\mathrm{Zn}$ & & & & & & & & & & 1 \\
\hline
\end{tabular}

Table 4 - Element correlations (Pearson) in cultivated species of Mentha piperita L.

Tablica 4 - Korelacija elemenata (Pearson) u kultiviranim vrstama Mentha piperita L.

\begin{tabular}{c|c|c|c|c|c|c|c|c|c|c|c}
\hline $\begin{array}{c}\text { Elements } \\
\text { Elementi }\end{array}$ & $\mathrm{Na}$ & $\mathrm{K}$ & $\mathrm{Ca}$ & $\mathrm{Mg}$ & $\mathrm{Cu}$ & $\mathrm{Cr}$ & $\mathrm{Mn}$ & $\mathrm{Ni}$ & $\mathrm{Fe}$ & $\mathrm{Pb}$ & $\mathrm{Zn}$ \\
\hline $\mathrm{Na}$ & 1 & -0.85 & 0.74 & 0.82 & 0.96 & -0.69 & 0.92 & 0.47 & 0.95 & -0.39 & -0.98 \\
\hline $\mathrm{K}$ & & 1 & -0.27 & -0.39 & -0.96 & 0.97 & -0.57 & -0.87 & -0.97 & -0.16 & 0.93 \\
\hline $\mathrm{Ca}$ & & & 1 & 0.99 & 0.51 & -0.03 & 0.95 & -0.24 & 0.48 & -0.91 & -0.59 \\
\hline $\mathrm{Mg}$ & & & & 1 & 0.62 & -0.16 & 0.98 & -0.12 & 0.59 & -0.84 & -0.69 \\
\hline $\mathrm{Cu}$ & & & & & 1 & -0.87 & 0.76 & 0.71 & 0.99 & -0.10 & -0.99 \\
\hline $\mathrm{Cr}$ & & & & & & 1 & -0.35 & -0.96 & -0.89 & -0.40 & 0.82 \\
\hline $\mathrm{Mn}$ & & & & & & & 1 & 0.08 & 0.74 & -0.72 & -0.82 \\
\hline $\mathrm{Ni}$ & & & & & & & & 1 & 0.73 & 0.63 & -0.64 \\
\hline $\mathrm{Fe}$ & & & & & & & & & 1 & -0.07 & -0.99 \\
\hline $\mathrm{Pb}$ & & & & & & & & & & 1 & 0.20 \\
\hline $\mathrm{Zn}$ & & & & & & & & & & & 1 \\
\hline
\end{tabular}

The strong correlation between $\mathrm{Ni}$ and $\mathrm{Pb}$, as well as $\mathrm{Ni}$ and $\mathrm{Fe}$, indicates primarily the influence of environmental factors in the case of Mentha longifoila L. and its cultivation (sources of heavy metal contamination in herb could be linked to irrigation water and polluted soil) and processing (due to harvesting and storage) in a sample of Mentha piperita L., since in this work, measured concentrations of $\mathrm{Ni}$ and $\mathrm{Pb}$ as toxic metals are lower than those obtained in other studies., ${ }^{72}$ As presented in Tables 3 and 4, full, strong, and moderate correlations were found between the measured elements. ${ }^{6,7,8,24}$ In general, full and moderate correlations were found between macro-elements and trace elements, which include alkaline earth cations as well as essential metals, i.e., $\mathrm{Cr}, \mathrm{Cu}, \mathrm{Zn}, \mathrm{Fe}$, and $\mathrm{Mn}$.

\subsection{Main essential elements (macro-elements)}

The metals $\mathrm{Ca}, \mathrm{Mg}, \mathrm{K}$, and $\mathrm{Na}$ represent the main essential macro-elements, available in high concentrations in almost all plant materials. In both species of Mentha, the highest concentrations were found for $\mathrm{K}\left(14.65-22.54 \mathrm{mg} \mathrm{g}^{-1}\right)$ and Ca $\left(9.08-15.53 \mathrm{mg} \mathrm{g}^{-1}\right)$, followed by $\mathrm{Na}$ and $\mathrm{Mg}(2.08-$ 4.12 and $1.93-3.12 \mathrm{mg} \mathrm{g}^{-1}$, respectively). These elements have important functions in plants as well as the human body. $\mathrm{K}$ maintains the fluid and electrolyte balance in the human body, and is responsible for transduction of nerve impulses, while $\mathrm{Ca}$ is the most abundant element in our body that helps form and maintain healthy bones. Mg has a key role in many enzymes as their central component; it 
plays a major role in overall cell functions including proteins, lipids, and carbohydrate metabolism. On the other hand, $\mathrm{Na}$ is responsible for depolarisation of cellular membrane, and for the water equilibrium in both, intra- and inter-cellular medium. Comparing the obtained results for macro-elements with the results of other authors, it was found that the concentrations of these elements were similar for samples of Mentha longifolia L. sample, while their concentrations varied greatly for samples of Mentha $\times$ piperita L. 5,12,14

\subsection{Essential trace elements (micro-elements)}

In the analysed species of Mentha, the highest concentrations of trace essential elements were found for Fe (619.30$\left.1108.40 \mathrm{mgg}^{-1}\right)$ and $\mathrm{Cu}\left(4.46-12.50 \mathrm{mg} \mathrm{g}^{-1}\right)$, followed by $\mathrm{Cr}, \mathrm{Zn}$, and $\mathrm{Mn}\left(0.70-0.90 \mathrm{mg} \mathrm{g}^{-1}, 13.90-39.30 \mathrm{mg} \mathrm{g}^{-1}\right.$, and 21.30-94.00 $\mathrm{mg} \mathrm{g}^{-1}$, respectively). The high concentration of Fe in herbs is due to fact that Fe originates mainly from soil and rock materials. The concentration of $\mathrm{Cr}$ was below detection limits in samples of wild Mentha herb. Essential micro-elements play an important role in the growth and development of plants and they also have many key biological and chemical functions in the human organism. Additionally, trace elements are a component of enzymes and hormones as a structural part of proteins and carbohydrate complexes involved in biochemical reactions in the human body. Zn and Fe together with enzymes are necessary for the proper functioning and maintenance of the immune system and a deficiency of one of them means a deficiency of the other metals. In addition, $\mathrm{Zn}$ is essential for the activity of numerous enzymes, while Fe is an essential element for living cells, and its deficiency is associated with anaemia. Mn is a micronutrient in plants as well as humans. It is a major contributor to various processes in plants including photosynthesis, respiration, and nitrogen assimilation. Deficiency of $\mathrm{Mn}$ in plants due to higher soil $\mathrm{pH}$ values and less use of fertilizers is similar to Fe deficiency, and leads to interveinal chlorosis of young leaves. $\mathrm{Mn}$ is a trace element and vital for human bodily functions because it contributes to the metabolism of amino acids, cholesterol, glucose, and carbohydrates. It also plays a role in bone formation, blood clotting, and reducing inflammation. Contents of $\mathrm{Zn}$ and Fe that were found in both Mentha species are a consequence of their bioavailability in plants, which were very similar, taking into account which forms were present from inorganic salts and organic matter contents of these two elements in the plant. Therefore, excess of $\mathrm{Zn}$ increased the level of Fe, and conversely, lower Fe concentrations correlate with lower $\mathrm{Zn}$ content. This was confirmed in this work, because higher concentrations of Fe and $\mathrm{Zn}$ were found in samples of both Mentha species, which were higher compared to the concentrations of these two elements measured in other studies. All of the above elements were present in values determined and confirmed by other authors. ${ }^{5,6,7,8,10,11,23,24}$

\subsection{Non-essential elements (heavy metals)}

Mentha herb, as a medicinal plant, may contain toxic elements, i.e., heavy metals originating from the environment, during processing, harvesting, or storage. Also, contamination of the herb with various heavy metals may occur during cultivation of the plant, as an impact of soil content, present nutrients, fertilizers, etc., as well as through processing and packaging of herb materials. Non-essential and toxic elements $\mathrm{Pb}$ and $\mathrm{Ni}$ were present almost in the same levels in both tested samples of Mentha species. $7,12,17,23,24$ In addition, in all samples, the measured content of $\mathrm{Pb}$ was significantly below recommended value of $10 \mathrm{mg} \mathrm{kg}^{-1}$ (WHO). ${ }^{19,21}$

\section{Conclusion}

The order of concentrations of essential and heavy metals in two Mentha species, wild and cultivated, determined by FAAS, was as follows: $\mathrm{K}>\mathrm{Ca}>\mathrm{Na}>\mathrm{Mg}>\mathrm{Fe}>\mathrm{Mn}>$ $\mathrm{Cu}>\mathrm{Zn}>\mathrm{Cr}>\mathrm{Ni}>\mathrm{Pb}$. Cadmium concentration was below the limit of detection by FAAS in all tested Mentha samples. The content of all metals were found to be in good agreement with those found in reported data of other authors/studies. These results show that both Mentha species are a good source of essential metals with low concentrations of heavy metals, and are safe for use both as a beverage and in different herbal formulations.

\section{DECLARATION OF CONFLICTING INTERESTS}

The author declares no potential conflict of interest with respect to the research, authorship, and/or publication of this article.

\section{FUNDING}

The author discloses the receipt of the following financial support for the research, authorship, and/or publication of this article: This research was supported by Ministry of Education and Science of the Federation of Bosnia and Herzegovina, and was carried out within the framework of the project "Determination of the content of macro- and micro-elements in selected samples of wild and cultivated representatives of the genus Mentha from Bosnia and Herzegovina" (Grant no. 05-39-2605-1/18, dated 12. 11. 2018)

\section{List of abbreviations Popis kratica}
AAS - atomic absorption spectrometry
- atomska apsorpcijska spektrometrija
FAAS - flame atomic absorption spectrometry - plamena atomska apsorpcijska spektrometrija
LOD - limit of detection
- granica detekcije
PTFE - polytetrafluoroethylene
- politetrafluoroetilen
SD - standard deviation
- standardna devijacija 


\section{References \\ Literatura}

1. E. F. S. David, M. M. Mischan, M. O. M. Marques, C. S. F. Boaro, Physiological indexese macro- and micronutrients in plant tissue and essential oil of Mentha piperita L. grown in nutrient solution with variation in N, P, K and Mg levels, Rev. Bras. Pl. Med. Campinas 16 (1) (2014) 97-106, doi: https:// doi.org/10.1590/S1516-05722014000100014.

2. P. Mikaili, S. Mojaverrostami, M. Moloudizargari, S. Aghajanshakeri, Pharmacological and therapeutic effects of Mentha Longifolia L. and its main constituent, menthol, Anc. Sci. Life 33 (2) (2013) 131-138, doi: https://doi.org/10.4103/02577941.139059.

3. P. S. C. Silva, L. S. Francisconi, R. D. M. R. Gonçalves, Evaluation of major and trace elements in medicinal plants, J. Braz. Chem. Soc. 27 (12) (2016) 2273-2289, doi: https:// doi.org/10.5935/0103-5053.20160123.

4. G. D. Gentscheva, T. Stafilov, E. H. Ivanova, Determination of some essential and toxic elements in herbs from Bulgaria and Macedonia using atomic spectrometry, Eurasian J. Anal. Chem. 5 (2) (2010) 104-111.

5. R. P. Choudhury, A. Kumar, A. N. Garg, Analysis of Indian mint (Mentha spicata) for essential, trace and toxic elements and its antioxidant behaviour, J. Pharm. Biomed. Anal. 41 (2006) 825-832, doi: https://doi.org/10.1016/j.jpba.2006.01.048.

6. V. K. Jena, S. Gupta, K. S. Patel, S. C. Patel, Evaluating heavy metals contents in medicinal plant Mentha longifolia, J. Mater. Environ. Sci. 4 (3) (2013) 384-389, url: https://www. jmaterenvironsci.com/Document/vol4/vol4_N3/48-JMES335-2012-Jena.pdf.

7. R. Dghaim, S. A. Khatib, H. Rasool, M. A. Khan, Determination of heavy metals concentration in traditional herbs commonly consumed in the United Arab Emirates, J. Environ. Public Health 2015 (2015) 1-6, doi: https://doi. org/10.1155/2015/973878.

8. A. A. Perić-Grujić, V. V. Pocajt, M. Đ. Ristić, Određivanje sadržaja teških metala u čajevima sa tržišta u Beogradu, Srbija, Hem. Ind. 63 (5) (2009) 433-436, doi: https://doi. org/10.2298/HEMIND0905433P.

9. J. Huremović, B. Braha, T. Muhić-Šarac, A. Selović, M. Memić, Sadržaj teških metala u začinskom bilju s tržišta u Sarajevu, Bosna i Hercegovina, Kem. Ind. 63 (3-4) (2014) 77-81, url: http://silverstripe.fkit.hr/kui/assets/Uploads/77.pdf.

10. Š. Mandal, N. Keškić, N. Marevac, The determination of iron levels in Menthae tea (Mentha piperita L.), Glas. hem. tehnol. Bosne Herceg. 48 (2017) 21-26, url: http://www.pmf. unsa.ba/hemija/glasnik/files/Issue\%2048\%20new/5-1-4_eki. pdf.

11. M. Bukva, D. Kapo, N. Huseinbašić, S. Gojak-Salimović, J. Huremović, Iron Content in Fruits, Vegetables, Herbs and Spices Samples Marketed in Sarajevo, Bosnia and Herzegovina, Kem. Ind. 68 (7-8) (2019) 281-287, doi: https://doi. org/10.15255/KUI.2019.001.

12. D. Kara, Evaluation of trace metal concentrations in some herbs and herbal teas by principal component analysis, Food Chem. 114 (2009) 347-354, doi: https://doi.org/10.1016/j. foodchem.2008.09.054.

13. A. Bielicka-Giełdoń, E. Ryłko, Estimation of metallic elements in herbs and spices available on the Polish market, Pol. J. Environ. Stud. 22 (4) (2013) 1251-1256, url:

14. http://www.pjoes.com/pdf-89086-22945?filename=Estimation\%20of\%20Metallic.pdf.

15. C. Rubio, J. R. D. Lucas, A. J. Gutiérrez, D. Glez-Weller, B. Pérez Marrero, J. M. Caballero, C. Revert, A. Hardisson, Evaluation of metal concentrations in mentha herbal teas (Mentha piperita, Mentha pulegium and Mentha species) by inductively coupled plasma spectrometry, J. Pharm. Biomed. Anal. 71 (2012) 11-7, doi: https://doi.org/10.1016/j. jpba.2012.07.015.

16. World Health Organization (WHO), Monographs on Selected Medicinal Plants - Volume 2, Berlin, Germany, 2004, pp. 199-205.

17. A. M. Alkherraz, A. M. Amer, A. M. Mlitan, Determination of some heavy metals in four medicinal plants, World Acad. Sci. Eng. Technol. 78 (2013) 1567-1570, url: https://www. researchgate.net/publication/284180501.

18. J. Mirosławski, A. Paukszto, Determination of the cadmium, chromium, nickel, and lead ions relays in selected Polish medicinal plants and their infusion, Biol. Trace Elem. Res. 182 (2018) 147-151, doi: https://doi.org/10.1007/s12011017-1072-5.

19. D. Kostić, S. Mitić, A. Zarubica, M. Mitić, J. Veličković, S. Randjelović, Content of trace metals in medicinal plants and their extracts, Hem. Ind. 65 (2) (2011) 165-170, doi: https:// doi.org/10.2298/HEMIND101005075K.

20. European Commission (EC). Commission regulation (EC) No 1881/2006 of 19 December 2006 setting maximum levels for certain contaminants in foodstuffs (Text with EEA relevance) (OJ L 364, 20.12.2006, p. 5).

21. S. Ražić, S. Đogo, Determination of chromium in Mentha piperita L. and soil by graphite furnace atomic absorption spectrometry after sequential extraction and microwave acid assisted digestion to assess potential bioavailability, Chemosphere 78(2010) 451-6, doi: https://doi. org/10.1016/j.chemosphere.2009.10.028.

22. World Health Organization (WHO). Quality Control Methods for Medicinal Plant Materials. World Health organization, Geneva, Switzerland, 1998

23. C. N. Jezler, P. A. O. Mangabeira, A.-A. Furtado de Almeida, R. M. de Jesus, R. A. de Oliveira, D. da Costa Silva, L. C. do Bomfim Costa, $\mathrm{Pb}$ and $\mathrm{Cd}$ on growth, leaf ultrastructure and essential oil yield mint (Mentha arvensis L.), Ciência Rural 45 (3) (2015) 392-398, doi: https://doi.org/10.1590/01038478 cr20130966.

24. I. Yener, Trace element analysis in some plants species by inductively coupled plasma optical emission spectrometry (ICP-OES), J. Inst. Sci. Technol. 9 (3) (2019) 1492-1502, doi: https://doi.org/10.21597/jist.517739.

25. N. Kočevar Glavač, S. Djogo, S. Ražić, S. Kreft, M. Veber, Accumulation of heavy metals from soil in medicinal plants, Arh. Hig. Rada. Toksikol. 68 (2017) 236-224, doi:

26. https://doi.org/10.1515/aiht-2017-68-2990.

27. J. Jain, Evaluation of trace metal in M. spicata for its therapeutic value, Int. J. Chem. Sci. 6 (3) (2008) 1500-1503, url: https:// www.tsijournals.com/articles/evaluation-of-trace-metal-in-m-spicata-for-its-therapeutic-value.pdf. 


\section{SAŽETAK \\ Sadržaj esencijalnih i teških metala u divljim i kultiviranim vrstama metvice iz Bosne i Hercegovine Šaćira Mandal}

Esencijalni i teški metali imaju ključnu ulogu na ljudsko zdravlje i bolesti. Cilj ove studije bio je odrediti koncentracije esencijalnih i teških metala kao što su $\mathrm{Na}, \mathrm{K}, \mathrm{Ca}, \mathrm{Mg}, \mathrm{Cu}, \mathrm{Cr}, \mathrm{Mn}, \mathrm{Ni}, \mathrm{Fe}, \mathrm{Pb}$, Zn i Cd u lišću Mentha longifolia L. i Mentha $\times$ piperita L. Uzorci biljnog materijala prikupljeni su sa šest različitih lokacija Bosne i Hercegovine $(\mathrm{BiH})$, na odabranim udaljenostima od izvora onečišćenja teškim metalima. Za otapanje uzoraka primijenjena je mokra digestija, a koncentracije esencijalnih i teških metala analizirane su plamenom atomskom apsorpcijskom spektrometrijom (PAAS). Rezultati analize (izraženi u mg g ${ }^{-1}$ ) dobiveni su kako slijedi: Na 2,08 - 4,12; K 14,85 - 22,54; Ca 9,06-15,53; Mg 1,93 - 3,12; Cu 0,01 - 0,05; Cr 0,70 - 0,90; Mn 0,02 - 0,09; Ni 1.10 - 7,00; Fe 0,06 - 1,11; Pb 0,10 - 0,90; Zn 0,01 - 0,04. Koncentracija kadmija od 0,002 $\mathrm{mgl}^{-1}$ bila je ispod granice detekcije PAAS-a. Snažna povezanost između Ni i Pb, kao i Ni i Fe, uglavnom je potvrdila utjecaj okoline i procesa prerade. Zaključno, Mentha longifolia L. i Mentha $\times$ piperita L. mogu se svakodnevno konzumirati s obzirom na visok sadržaj Fe, Cu, Mg i Zn i njihove blagotvorne učinke na normalno funkcioniranje organizma. Dodatno, nakon konzumiranja tih uzoraka ne postoji rizik od teških metala za ljudsko zdravlje zbog niskih koncentracija.

\section{Ključne riječi}

Esencijalni metali, teški metali, vrste metvice, AAS

Univerzitet u Sarajevu

Farmaceutski fakultet

Zmaja od Bosne 8

71000 Sarajevo

Bosna i Hercegovina
Izvorni znanstveni rad Prispjelo 6. listopada 2020. Prihvaćeno 17. prosinca 2020. 